\title{
Synthesis and characterization of dodecahedral cerium(IV) and gadolinium(III) complexes with a tetradentate Schiff Base
}

\author{
TULIKA GHOSH and SAMUDRANIL PAL* \\ School of Chemistry, University of Hyderabad, Hyderabad 500 046, India \\ e-mail: spal@uohyd.ac.in
}

MS received 8 December 2014; revised 18 March 2015; accepted 22 March 2015

\begin{abstract}
Reactions of $\mathrm{CeCl}_{3} \cdot 6 \mathrm{H}_{2} \mathrm{O}$ and $\mathrm{Gd}\left(\mathrm{NO}_{3}\right)_{3} \cdot 5 \mathrm{H}_{2} \mathrm{O}$ with biacetyl bis(benzoylhydrazone) $\left(\mathrm{H}_{2}\right.$ babh) and $\mathrm{KOH}$ in 1:2:2 mole ratio in methanol afford the complexes [Ce(babh) $\left.)_{2}\right](\mathbf{1})$ and $[\mathrm{Gd}(\mathrm{babh})(\mathrm{Hbabh})] \cdot \mathrm{H}_{2} \mathrm{O}$ $\left(\mathbf{2} \cdot \mathrm{H}_{2} \mathrm{O}\right)$, respectively in good yields. Characterization of the complexes has been performed with the help of elemental analysis, magnetic susceptibility, spectroscopic (IR, UV-Vis, EPR and NMR) and X-ray crystallographic measurements. $\mathbf{1}$ is diamagnetic and NMR active, while $\mathbf{2} \cdot \mathrm{H}_{2} \mathrm{O}$ is paramagnetic $\left(\mu_{\mathrm{eff}}=8.03 \mu_{\mathrm{B}}\right.$ at 300 $\mathrm{K})$ and EPR active. The complexes crystallize as $\mathbf{1} \cdot \mathrm{CH}_{2} \mathrm{Cl}_{2}$ and $\mathbf{2} \cdot \mathrm{H}_{2} \mathrm{O}$. X-ray structures show that the metal centre in each of $\mathbf{1}$ and $\mathbf{2}$ is in a distorted dodecahedral $\mathrm{N}_{4} \mathrm{O}_{4}$ coordination sphere assembled by two meridionally spanning ONNO-donor ligands. Self-assembly of $\mathbf{1} \cdot \mathrm{CH}_{2} \mathrm{Cl}_{2}$ via intermolecular $\mathrm{C}-\mathrm{H} \cdots \mathrm{N}$ and $\mathrm{C}-\mathrm{H} \cdots \mathrm{Cl}$ hydrogen bonds and $\pi-\pi$ interactions provides one-dimensional 'ladder' type structure. On the other hand, 2. $\mathrm{H}_{2} \mathrm{O}$ assembles into a two-dimensional 'sheet' like network through intermolecular $\mathrm{N}-\mathrm{H} \cdots \mathrm{O}$ and $\mathrm{O}-\mathrm{H} \cdots \mathrm{N}$ hydrogen bonds.
\end{abstract}

Keywords. Cerium(IV); Gadolinium(III); Tetradentate ligand; Dodecahedral; Physical properties.

\section{Introduction}

In recent years, coordination complexes of lanthanides have drawn immense attention due to their versatile applications in various areas of chemical, biomedical and materials research. Lanthanide metal ions are very different when compared with transition metal ions. They have large ionic radii and hence they can easily form complexes with coordination numbers more than six and the accompanying uncommon coordination geometries. ${ }^{1,2}$ Trivalent lanthanides have very distinctive photophysical properties. They display large Stokes shifts and sharp emission bands from long-lived excited states. High magnetic moments, large magnetic anisotropy and the electron spin relaxation behaviors make the trivalent lanthanides unique with respect to their magnetic properties. All these features have led to the use of lanthanide complexes as chirality probes for biological sub strates, ${ }^{3,4}$ photocytotoxic agents, ${ }^{5}$ luminescence sensors and imaging agents, ${ }^{6-8}$ photo-emitting materials, ${ }^{9-11}$ single molecule and single chain magnets ${ }^{12-15}$ and contrast agents in magnetic resonance imaging. ${ }^{16-19}$ Some lanthanide complexes are also used as catalysts in organic synthesis. ${ }^{20-22}$ Due to the above mentioned wide variety

*For correspondence of applications there is a continuous quest for new lanthanide complexes.

Recently, we have reported two mononuclear complexes of nickel(II) and copper(II) and a double helical dicopper(II) complex with the tetradentate Schiff base biacetyl bis(benzoylhydrazone) ( $\mathrm{H}_{2}$ babh, 2 H's represent the two dissociable amide protons). ${ }^{23,24}$ In the mononuclear complexes, the dianionic ligand $\left(\mathrm{babh}^{2-}\right)$ provides the expected $\mathrm{N}_{2} \mathrm{O}_{2}$ square-plane around the metal centre and forms 5,5,5-membered fused chelate rings. ${ }^{23}$ On the other hand, each bridging ligand in $\left[\mathrm{Cu}_{2}(\mu \text {-babh })_{2}\right]$ is twisted along the single bond of its $=\left(\mathrm{CH}_{3}\right) \mathrm{C}-\mathrm{C}\left(\mathrm{CH}_{3}\right)=$ fragment to accommodate the two metal centres. ${ }^{24}$ Thus, apparently rigid babh $^{2-}$ is rather flexible and can adopt an unusual bridging coordination mode to provide the double helical motif of the dicopper(II) complex. Since lanthanide ions can have high $(>6)$ coordination numbers and hence unusual coordination geometries, complexes of them with not so rigid tetradentate babh $^{2-}$ is anticipated to be interesting. In this work, we have investigated the complexation behavior of $\mathrm{H}_{2}$ babh with cerium and gadolinium ions and isolated the octacoordinated dodecahedral cerium(IV) and gadolinium(III) complexes having the formulas $\left[\mathrm{Ce}(\mathrm{babh})_{2}\right]$ (1) and $[\mathrm{Gd}(\mathrm{babh})(\mathrm{Hbabh})]$ (2), respectively (Chart 1). Herein we describe the syntheses, physical properties and crystal structures of these two complexes. 

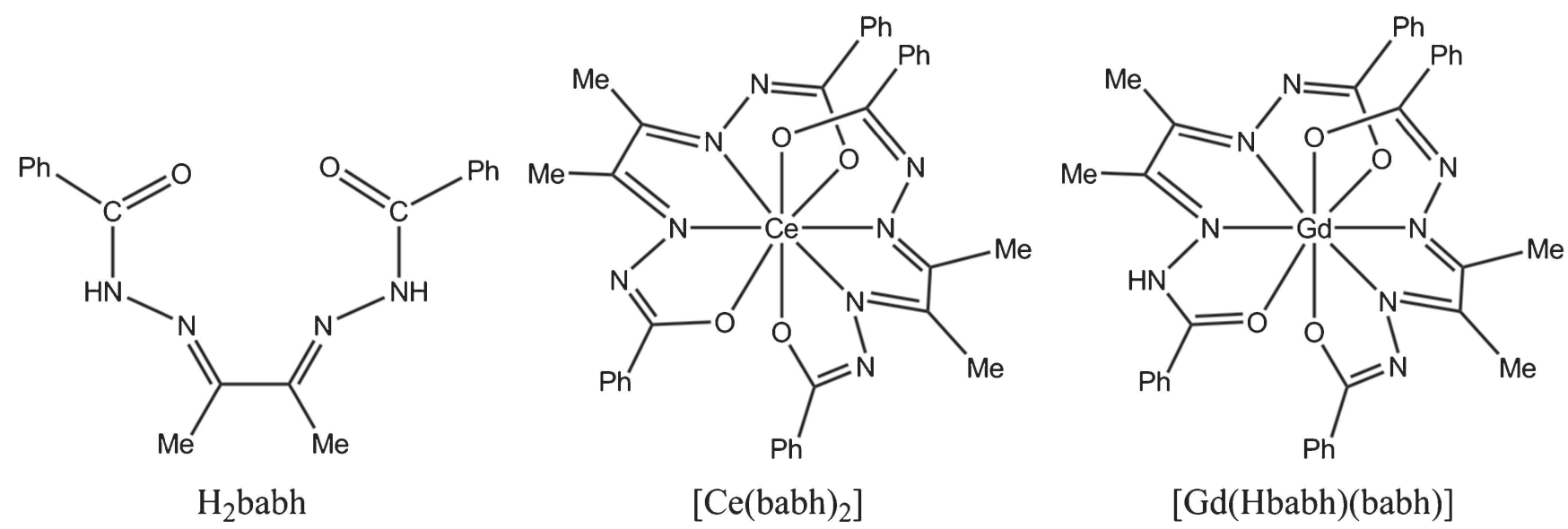

Chart 1. $\mathrm{H}_{2}$ babh and its complexes with cerium(IV) and gadolinium(III).

\section{Experimental}

\subsection{Materials}

The Schiff base biacetyl bis(benzoylhydrazone) $\left(\mathrm{H}_{2}\right.$ babh) was synthesized by following our previously reported procedure. ${ }^{23}$ All other chemicals and solvents were of analytical grade available commercially and were used as received.

\subsection{Physical measurements}

A Thermo Finnigan Flash EA1112 series elemental analyzer was used for the microanalytical (CHN) measurements. Infrared spectra were recorded by using $\mathrm{KBr}$ pellets on a Jasco-5300 FT-IR spectrophotometer. A Shimadzu UV-3600 UV-VIS-NIR spectrophotometer was used to record the electronic spectra. The ${ }^{1} \mathrm{H}$ NMR spectrum of the cerium(IV) complex was collected on a Bruker $400 \mathrm{MHz}$ NMR spectrometer. X-band EPR measurements with the gadolinium(III) complex were performed on a Jeol JES-FA200 spectrometer. A Digisun DI-909 conductivity meter was used to measure the solution electrical conductivities. Room temperature magnetic susceptibilities were measured using a Sherwood Scientific balance. Variable temperature magnetic susceptibility measurements were performed with the help of a Quantum Design SQUID VSM. Diamagnetic corrections calculated from Pascal's constants ${ }^{25}$ were used to obtain the molar paramagnetic susceptibilities.

\subsection{Synthesis of $\left[\mathrm{Ce}(\mathrm{babh})_{2}\right](\mathbf{1})$}

A methanol (4 mL) solution of $\mathrm{KOH}(40 \mathrm{mg}, 0.71 \mathrm{mmol})$ was added to a methanol $(25 \mathrm{~mL})$ solution of $\mathrm{H}_{2}$ babh (100 mg, $0.31 \mathrm{mmol}$ ) and the mixture was stirred at $50^{\circ} \mathrm{C}$ for $1 / 2 \mathrm{~h}$ to obtain a clear solution. To this solution a methanol $(10 \mathrm{~mL})$ solution of $\mathrm{CeCl}_{3} \cdot 6 \mathrm{H}_{2} \mathrm{O}(53 \mathrm{mg}$, $0.15 \mathrm{mmol}$ ) was added slowly, refluxed for $1 \mathrm{~h}$ and then cooled to room temperature. The dark microcrystalline solid deposited was collected by filtration and dried in air. The yield was $80 \mathrm{mg}(68 \%)$. Anal. calcd for $\mathrm{CeC}_{36} \mathrm{H}_{32} \mathrm{~N}_{8} \mathrm{O}_{4}$ : C, 55.38; H, 4.13; N, 14.35\%. Found: C, 55.53; $\mathrm{H}, 4.21 ; \mathrm{N}, 14.16 \%$. UV-Vis in $\mathrm{CH}_{2} \mathrm{Cl}_{2}$ solution: $\lambda(\mathrm{nm})\left(\varepsilon\left(10^{3} \mathrm{M}^{-1} \mathrm{~cm}^{-1}\right)\right)=510 \mathrm{sh}(9.2), 400$ (44.2), 365sh (40.3), 283 (61.9), 265sh (58.6).

\subsection{Synthesis of $[\mathrm{Gd}(\mathrm{babh})(\mathrm{Hbabh})] \cdot \mathrm{H}_{2} \mathrm{O}\left(2 \cdot \mathrm{H}_{2} \mathrm{O}\right)$}

A methanol (4 mL) solution of $\mathrm{KOH}(40 \mathrm{mg}, 0.71 \mathrm{mmol})$ was added to a methanol $(25 \mathrm{~mL})$ solution of $\mathrm{H}_{2}$ babh (100 $\mathrm{mg}, 0.31 \mathrm{mmol})$ and stirred for $10 \mathrm{~min}$ at room temperature. Then a methanol $(10 \mathrm{~mL})$ solution of $\mathrm{Gd}\left(\mathrm{NO}_{3}\right)_{3} \cdot 5 \mathrm{H}_{2} \mathrm{O}(65 \mathrm{mg}, 0.15 \mathrm{mmol})$ was added to the mixture of $\mathrm{H}_{2}$ babh and $\mathrm{KOH}$ and stirred for 7 hours. The resulting yellow solution was evaporated to about $5 \mathrm{~mL}$. A yellow amorphous powder precipitated within 2-3 days was collected by filtration. The yield was $90 \mathrm{mg}$ (73\%). Anal. calcd for $\mathrm{GdC}_{36} \mathrm{H}_{35} \mathrm{~N}_{8} \mathrm{O}_{5}$ : C, 52.93; H, 4.32; N, $13.71 \%$. Found: C, 52.95; H, 4.59; N, $13.48 \%$. UV-Vis in $\mathrm{CH}_{2} \mathrm{Cl}_{2}$ solution: $\lambda(\mathrm{nm})\left(\varepsilon\left(10^{3} \mathrm{M}^{-1} \mathrm{~cm}-1\right)\right)$ $=460 \mathrm{sh}$ (27.1), 430sh (48.8), 415 (50.7), 305sh (30.4), 263 (43.2).

\section{$2.5 X$-ray crystallography}

Single crystals of the cerium(IV) complex (1) were obtained by diffusion of $n$-hexane into its dichloromethane solution as $\mathbf{1} \cdot \mathrm{CH}_{2} \mathrm{Cl}_{2}$. On the other hand, single crystals of the mono hydrated gadolinium(III) complex $\left(\mathbf{2} \cdot \mathrm{H}_{2} \mathrm{O}\right)$ were grown by slow evaporation of its dichloromethane solution. A Bruker-Nonius SMART APEX CCD single crystal diffractometer equipped with a graphite monochromator and a Mo $K \alpha$ fine-focus 
sealed tube $(\lambda=0.71073 \AA$ ) was used for the determination of unit cell parameters and intensity data collections at $100 \mathrm{~K}$ for each of $\mathbf{1} \cdot \mathrm{CH}_{2} \mathrm{Cl}_{2}$ and $\mathbf{2} \cdot \mathrm{H}_{2} \mathrm{O}$. The SMART software was used for data acquisition and the SAINT-Plus software was used for data extraction. ${ }^{26}$ The absorption corrections were performed with the help of SADABS program. ${ }^{27}$ The structures of $\mathbf{1} \cdot \mathrm{CH}_{2} \mathrm{Cl}_{2}$ and $\mathbf{2} \cdot \mathrm{H}_{2} \mathrm{O}$ were solved in the monoclinic space groups $P 2_{1} / \mathrm{c}$ and $C 2 / \mathrm{c}$, respectively by direct methods and refined on $F^{2}$ by full-matrix least-squares procedures. In each case, the asymmetric unit contains a whole complex molecule with the corresponding solvent molecule. In case of $\mathbf{2} \cdot \mathrm{H}_{2} \mathrm{O}$, one of the phenyl rings of $\mathrm{Hbabh}^{-}$is disordered. Four carbon atoms of this phenyl ring are located at eight positions that are related by a two-fold axis passing through the remaining two para carbon atoms. The disordered carbon atoms located at eight positions (each having half site occupancy) were refined isotropically with geometric restraints. All nonhydrogen atoms in $\mathbf{1} \cdot \mathrm{CH}_{2} \mathrm{Cl}_{2}$ and those with full site occupancies in $\mathbf{2} \cdot \mathrm{H}_{2} \mathrm{O}$ were refined using anisotropic thermal parameters. The hydrogen atoms of the water molecule in $\mathbf{2} \cdot \mathrm{H}_{2} \mathrm{O}$ were located in a difference Fourier map and refined with $U_{\text {iso }}(\mathrm{H})=1.5 U_{\text {iso }}(\mathrm{O})$ and geometric restraints. The remaining hydrogen atoms in $\mathbf{2} \cdot \mathrm{H}_{2} \mathrm{O}$ and all the hydrogen atoms in $\mathbf{1} \cdot \mathrm{CH}_{2} \mathrm{Cl}_{2}$ were included in the structure factor calculations at idealized positions by using a riding model. The SHELX-97 programs $^{28}$ available in the WinGX package ${ }^{29}$ were used for structure solution and refinement. The Mercury ${ }^{30}$ and Platon ${ }^{31}$ packages were used for molecular graphics. Selected crystallographic data are listed in table 1 .

\section{Results and Discussion}

\subsection{Synthesis}

[Ce(babh) $)_{2}$ (1) and mono hydrated [Gd(babh)(Hbabh)] $\left(2 \cdot \mathrm{H}_{2} \mathrm{O}\right)$ have been synthesized in 68 and $73 \%$ yields, respectively by reacting one mole equivalent of the corresponding hydrated trivalent metal ion salt $\left(\mathrm{CeCl}_{3}\right.$. $6 \mathrm{H}_{2} \mathrm{O}$ and $\left.\mathrm{Gd}\left(\mathrm{NO}_{3}\right)_{3} \cdot 5 \mathrm{H}_{2} \mathrm{O}\right)$, two mole equivalents of biacetyl bis(benzoylhydrazone) $\left(\mathrm{H}_{2}\right.$ babh) and little more than four mole equivalents of $\mathrm{KOH}$ in methanol. 1 has been isolated as a dark microcrystalline material, while $\mathbf{2} \cdot \mathrm{H}_{2} \mathrm{O}$ has been obtained as an amorphous yellow powder. The elemental (CHN) analysis data of $\mathbf{1}$ and $\mathbf{2} \cdot \mathrm{H}_{2} \mathrm{O}$ are in good agreement with the corresponding molecular formulas. The room temperature $(300 \mathrm{~K})$ effective magnetic moment $\left(\mu_{\text {eff }}\right)$ value $\left(8.03 \mu_{\mathrm{B}}\right)$ of $2 \cdot \mathrm{H}_{2} \mathrm{O}$ is very close to the spin-only value expected for an $\mathrm{f}^{7}$ metal ion. Thus the gadolinium centre in $\mathbf{2}$ is in the trivalent state. On the other hand, the diamagnetic nature of $\mathbf{1}$ confirms the +4 oxidation state of its cerium centre. Both complexes are highly soluble in dichloromethane, chloroform, methanol, dimethylsulfoxide and acetone. $\mathbf{1}$ affords a brown solution whereas $\mathbf{2} \cdot \mathrm{H}_{2} \mathrm{O}$ produces a yellow solution. Both complexes behave as nonelectrolyte in solution.

Table 1. Selected crystallographic data for $\mathbf{1} \cdot \mathrm{CH}_{2} \mathrm{Cl}_{2}$ and $\mathbf{2} \cdot \mathrm{H}_{2} \mathrm{O}$.

\begin{tabular}{|c|c|c|}
\hline Complex & 1. $\mathrm{CH}_{2} \mathrm{Cl}_{2}$ & $2 \cdot \mathrm{H}_{2} \mathrm{O}$ \\
\hline Chemical formula & $\mathrm{CeC}_{37} \mathrm{H}_{34} \mathrm{~N}_{8} \mathrm{O}_{4} \mathrm{Cl}_{2}$ & $\mathrm{GdC}_{36} \mathrm{H}_{35} \mathrm{~N}_{8} \mathrm{O}_{5}$ \\
\hline Formula weight $\left(\mathrm{g} \mathrm{mol}^{-1}\right)$ & 865.74 & 816.98 \\
\hline Crystal system & Monoclinic & Monoclinic \\
\hline Space group & $P 2{ }_{1} / \mathrm{c}$ & $C 2 / \mathrm{c}$ \\
\hline$a(\AA)$ & $11.5199(9)$ & $27.003(6)$ \\
\hline$b(\AA)$ & $25.818(2)$ & $20.395(5)$ \\
\hline$c(\AA)$ & $12.7913(11)$ & $19.854(5)$ \\
\hline$\beta\left(^{\circ}\right)$ & $104.362(1)$ & $128.806(3)$ \\
\hline Volume $\left(\AA^{3}\right)$ & $3685.6(5)$ & $8521(3)$ \\
\hline$Z$ & 4 & 8 \\
\hline Calculated density $\left(\mathrm{g} \mathrm{cm}^{-3}\right)$ & 1.560 & 1.274 \\
\hline Absorption coefficient $\left(\mathrm{mm}^{-1}\right)$ & 1.431 & 1.601 \\
\hline Reflections collected & 35070 & 29912 \\
\hline Unique reflections & 6495 & 7474 \\
\hline Reflections $[I \geq 2 \sigma(I)]$ & 6358 & 5228 \\
\hline Data/restraints/Parameters & $6495 / 0 / 469$ & $7474 / 40 / 455$ \\
\hline$R 1, w R 2[I \geq 2 \sigma(I)]$ & $0.0231,0.0581$ & $0.0935,0.2044$ \\
\hline$R 1, w R 2$ (all data) & $0.0237,0.0585$ & $0.1354,0.2212$ \\
\hline Goodness-of-fit on $F^{2}$ & 1.124 & 1.140 \\
\hline Largest peak and hole $\left(\mathrm{e} \AA^{-3}\right)$ & $0.432,-0.497$ & $2.693,-2.608$ \\
\hline
\end{tabular}




\subsection{Molecular structures}

The structures of $\mathbf{1} \cdot \mathrm{CH}_{2} \mathrm{Cl}_{2}$ and $\mathbf{2} \cdot \mathrm{H}_{2} \mathrm{O}$ are illustrated in figure 1 . The bond lengths and the bond angles related to the metal centres are given in table 2. In general, the metal to coordinating atom $(\mathrm{O}$ and $\mathrm{N})$ bond lengths in $\mathbf{1}$ and $\mathbf{2}$ are within the ranges reported for cerium(IV) and gadolinium(III) complexes, respectively having similar coordinating atoms. ${ }^{32-34}$ In each of $\mathbf{1}$ and $\mathbf{2}$, the ligands act as ONNO-donors and form 5,5,5-membered fused chelate rings and a distorted dodecahedral $\mathrm{N}_{4} \mathrm{O}_{4}$ coordination sphere around the metal centre (figure 2). The $\mathrm{C}-\mathrm{O}(1.298(3)-1.304(2) \AA)$ and the $\mathrm{C}-\mathrm{N}$ bond lengths $(1.308(3)-1.312(3) \AA)$ of the $-\mathrm{C}\left(\mathrm{O}^{-}\right)=\mathrm{N}-$ fragments of the two ligands $\left(\mathrm{babh}^{2-}\right)$ are consistent with the deprotonated form of each of the four amide functionalities in $\mathbf{1}^{23,24}$ On the other hand, the $\mathrm{C}(12)-\mathrm{O}(2)$

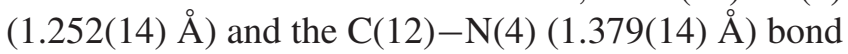
lengths are noticeably shorter and longer, respectively compared to the C-O (1.271(14)-1.299(14) $\AA$ ) and the $\mathrm{C}-\mathrm{N}$ bond lengths $(1.291(14)-1.327(15) \AA)$ of the other three amide functionalities in 2 (figure $1 \mathrm{~b}$ ). Thus, here one ligand $\left(\mathrm{Hbabh}^{-}\right)$has one protonated and one deprotonated amide functionality, while both amide functionalities of the other ligand $\left(\mathrm{babh}^{2-}\right)$ are deprotonated. In both $\mathbf{1}$ and 2, 5,5,5-membered fused chelate rings formed by each ONNO-donor ligand excluding the phenyl rings are satisfactorily coplanar (mean deviations $0.03-0.11 \AA$ ). The dihedral angles between the two planes each containing 5,5,5-membered chelate rings are $89.8(1)^{\circ}$ and $83.1(1)^{\circ}$ for $\mathbf{1}$ and $\mathbf{2}$, respectively. Thus the two ligands are essentially orthogonal to each other and hence meridional in $\mathbf{1}$ as well as in $\mathbf{2}$ (figure 1). In both complexes, each phenyl ring is twisted along the $\mathrm{C}-\mathrm{C}$ bond that connects it with the terminal chelate ring. In 1, the dihedral angles formed by the two phenyl ring planes with the mean plane containing the corresponding 5,5,5-membered fused chelate rings span the range $9.5(1)^{\circ}-18.9(1)^{\circ}$. In case of $2, \mathrm{C}(13)-\mathrm{C}(18)$ phenyl ring is disordered (figure $1 \mathrm{~b}$ ). Four carbon atoms $(\mathrm{C}(14), \mathrm{C}(15), \mathrm{C}(17)$ and $\mathrm{C}(18))$ of this phenyl ring are located at eight positions that are related by a twofold axis passing through $\mathrm{C}(13)$ and $\mathrm{C}(16)$. The dihedral angles formed by these two orientations of the $\mathrm{C}(13)-\mathrm{C}(18)$ phenyl ring with the plane containing the corresponding 5,5,5-membered fused chelate rings are $38(1)^{\circ}$ and $56(1)^{\circ}$. The analogous dihedral angles for the remaining three phenyl rings are within $15(1)^{\circ}-$ $22.8(6)^{\circ}$.

\subsection{Supramolecular structures}

Supramolecular structures via intermolecular noncovalent interactions for both $\mathbf{1} \cdot \mathrm{CH}_{2} \mathrm{Cl}_{2}$ and $\mathbf{2} \cdot \mathrm{H}_{2} \mathrm{O}$ have been scrutinized. The solvent molecules trapped in the crystal lattices play crucial roles in directing the supramolecular structures by participating in intermolecular hydrogen bonding interactions. These hydrogen bonds are unconventional for $\mathbf{1} \cdot \mathrm{CH}_{2} \mathrm{Cl}_{2}$, while they are conventional for $\mathbf{2} \cdot \mathrm{H}_{2} \mathrm{O}$ (table 3 ). In addition to the
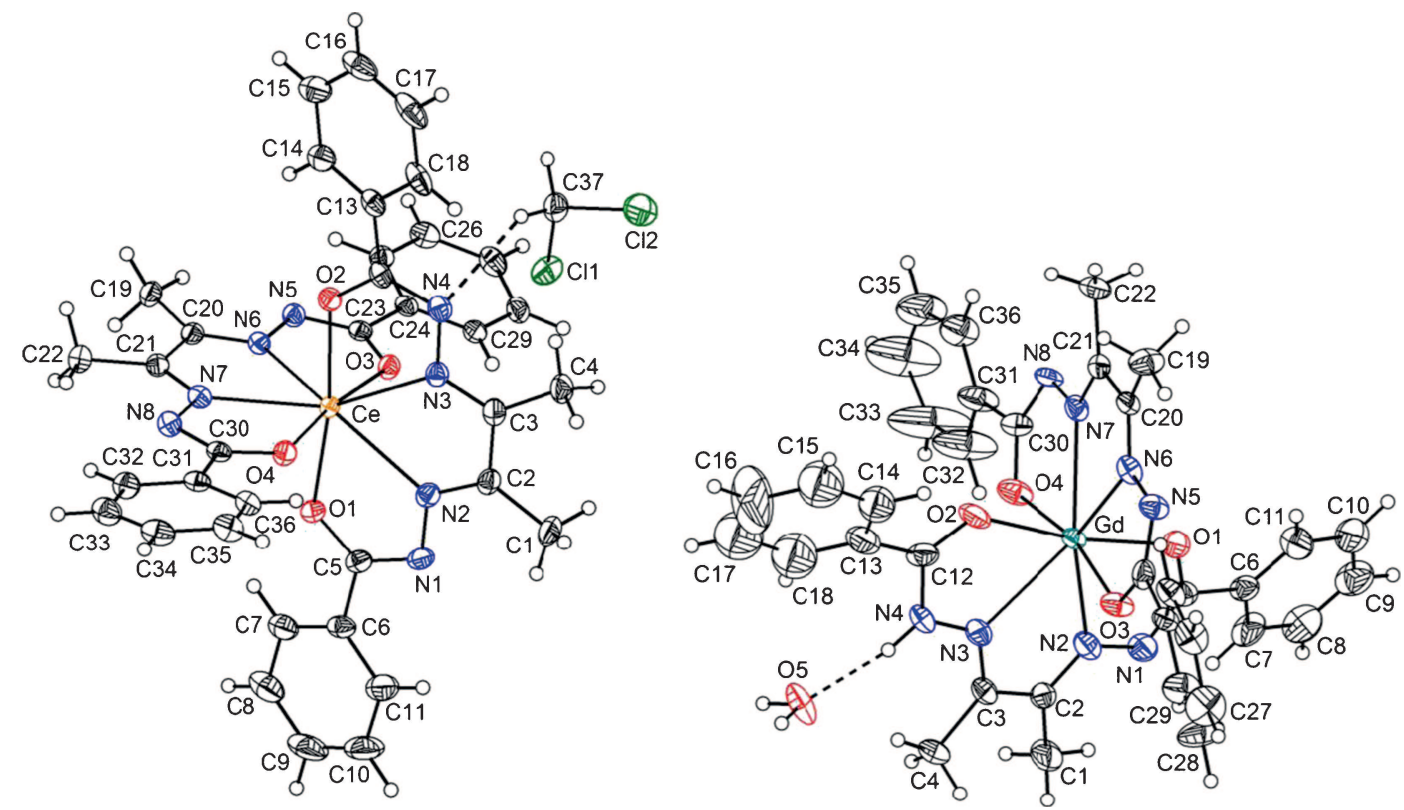

Figure 1. Structures of (a) $\left[\mathrm{Ce}(\mathrm{babh})_{2}\right] \cdot \mathrm{CH}_{2} \mathrm{Cl}_{2}\left(\mathbf{1} \cdot \mathrm{CH}_{2} \mathrm{Cl}_{2}\right)$ and (b) $[\mathrm{Gd}(\mathrm{babh})(\mathrm{Hbabh})] \cdot \mathrm{H}_{2} \mathrm{O}$ $\left(\mathbf{2} \cdot \mathrm{H}_{2} \mathrm{O}\right)$. All non-hydrogen atoms are represented by $50 \%\left(\right.$ in $\left.\mathbf{1} \cdot \mathrm{CH}_{2} \mathrm{Cl}_{2}\right)$ and $30 \%\left(\right.$ in $\left.\mathbf{2} \cdot \mathrm{H}_{2} \mathrm{O}\right)$ probability thermal ellipsoids. For clarity, a few carbon atoms are not labeled and only one orientation of the disordered phenyl ring $(\mathrm{C} 13-\mathrm{C} 18)$ of $\mathbf{2} \cdot \mathrm{H}_{2} \mathrm{O}$ is shown. 
hydrogen bonds, $\pi-\pi$ interactions also take part in shaping the final supramolecular structure of $\mathbf{1} \cdot \mathrm{CH}_{2} \mathrm{Cl}_{2}$.

In the crystal lattice, $\mathbf{1} \cdot \mathrm{CH}_{2} \mathrm{Cl}_{2}$ units exist as dimers. In the dimeric unit, each $\mathrm{CH}_{2} \mathrm{Cl}_{2}$ participate in a

Table 2. Selected bond lengths ( $)$ ) and angles $\left(^{\circ}\right)$ for 1. $\mathrm{CH}_{2} \mathrm{Cl}_{2}$ and $2 \cdot \mathrm{H}_{2} \mathrm{O}$.

\begin{tabular}{|c|c|c|}
\hline Bond parameter & $\mathbf{1} \cdot \mathrm{CH}_{2} \mathrm{Cl}_{2}(\mathrm{M}=\mathrm{Ce})$ & $\mathbf{2} \cdot \mathrm{H}_{2} \mathrm{O}(\mathrm{M}=\mathrm{Gd})$ \\
\hline $\mathrm{M}-\mathrm{O}(1)$ & $2.2671(15)$ & $2.326(8)$ \\
\hline $\mathrm{M}-\mathrm{O}(2)$ & $2.2651(15)$ & $2.408(9)$ \\
\hline $\mathrm{M}-\mathrm{O}(3)$ & $2.2650(15)$ & $2.326(7)$ \\
\hline $\mathrm{M}-\mathrm{O}(4)$ & $2.2719(15)$ & $2.313(8)$ \\
\hline $\mathrm{M}-\mathrm{N}(2)$ & $2.5095(18)$ & $2.503(10)$ \\
\hline $\mathrm{M}-\mathrm{N}(3)$ & $2.5073(18)$ & $2.564(9)$ \\
\hline $\mathrm{M}-\mathrm{N}(6)$ & $2.5101(17)$ & $2.494(9)$ \\
\hline $\mathrm{M}-\mathrm{N}(7)$ & $2.5089(18)$ & $2.489(9)$ \\
\hline $\mathrm{O}(1)-\mathrm{M}-\mathrm{O}(2)$ & $171.37(5)$ & $171.8(3)$ \\
\hline $\mathrm{O}(1)-\mathrm{M}-\mathrm{O}(3)$ & $88.94(6)$ & $95.8(3)$ \\
\hline $\mathrm{O}(1)-\mathrm{M}-\mathrm{O}(4)$ & $91.10(6)$ & $90.0(3)$ \\
\hline $\mathrm{O}(1)-\mathrm{M}-\mathrm{N}(2)$ & $63.22(6)$ & $63.8(3)$ \\
\hline $\mathrm{O}(1)-\mathrm{M}-\mathrm{N}(3)$ & $125.33(5)$ & $124.8(3)$ \\
\hline $\mathrm{O}(1)-\mathrm{M}-\mathrm{N}(6)$ & $90.71(5)$ & $94.5(3)$ \\
\hline $\mathrm{O}(1)-\mathrm{M}-\mathrm{N}(7)$ & $89.55(5)$ & $88.9(3)$ \\
\hline $\mathrm{O}(2)-\mathrm{M}-\mathrm{O}(3)$ & $91.82(6)$ & $86.4(3)$ \\
\hline $\mathrm{O}(2)-\mathrm{M}-\mathrm{O}(4)$ & $89.40(5)$ & $89.3(3)$ \\
\hline $\mathrm{O}(2)-\mathrm{M}-\mathrm{N}(2)$ & $125.40(6)$ & $124.2(3)$ \\
\hline $\mathrm{O}(2)-\mathrm{M}-\mathrm{N}(3)$ & $63.30(6)$ & $63.3(3)$ \\
\hline $\mathrm{O}(2)-\mathrm{M}-\mathrm{N}(6)$ & $81.97(5)$ & $79.3(3)$ \\
\hline $\mathrm{O}(2)-\mathrm{M}-\mathrm{N}(7)$ & $82.97(6)$ & $83.5(3)$ \\
\hline $\mathrm{O}(3)-\mathrm{M}-\mathrm{O}(4)$ & $171.69(5)$ & $167.9(3)$ \\
\hline $\mathrm{O}(3)-\mathrm{M}-\mathrm{N}(2)$ & $83.06(5)$ & $87.8(3)$ \\
\hline $\mathrm{O}(3)-\mathrm{M}-\mathrm{N}(3)$ & $85.35(5)$ & $82.3(3)$ \\
\hline $\mathrm{O}(3)-\mathrm{M}-\mathrm{N}(6)$ & $63.28(5)$ & $64.7(3)$ \\
\hline $\mathrm{O}(3)-\mathrm{M}-\mathrm{N}(7)$ & $125.03(5)$ & $126.7(3)$ \\
\hline $\mathrm{O}(4)-\mathrm{M}-\mathrm{N}(2)$ & $89.54(6)$ & $85.2(3)$ \\
\hline $\mathrm{O}(4)-\mathrm{M}-\mathrm{N}(3)$ & $87.86(6)$ & $85.6(3)$ \\
\hline $\mathrm{O}(4)-\mathrm{M}-\mathrm{N}(6)$ & $125.03(5)$ & $125.5(3)$ \\
\hline $\mathrm{O}(4)-\mathrm{M}-\mathrm{N}(7)$ & $63.28(5)$ & $63.9(3)$ \\
\hline $\mathrm{N}(2)-\mathrm{M}-\mathrm{N}(3)$ & $62.11(6)$ & $61.0(3)$ \\
\hline $\mathrm{N}(2)-\mathrm{M}-\mathrm{N}(6)$ & $138.23(6)$ & $143.8(3)$ \\
\hline $\mathrm{N}(2)-\mathrm{M}-\mathrm{N}(7)$ & $141.82(6)$ & 139.2(3) \\
\hline $\mathrm{N}(3)-\mathrm{M}-\mathrm{N}(6)$ & $132.49(6)$ & $131.5(3)$ \\
\hline $\mathrm{N}(3)-\mathrm{M}-\mathrm{N}(7)$ & $136.13(6)$ & $135.3(3)$ \\
\hline $\mathrm{N}(6)-\mathrm{M}-\mathrm{N}(7)$ & $61.80(5)$ & $61.9(3)$ \\
\hline
\end{tabular}

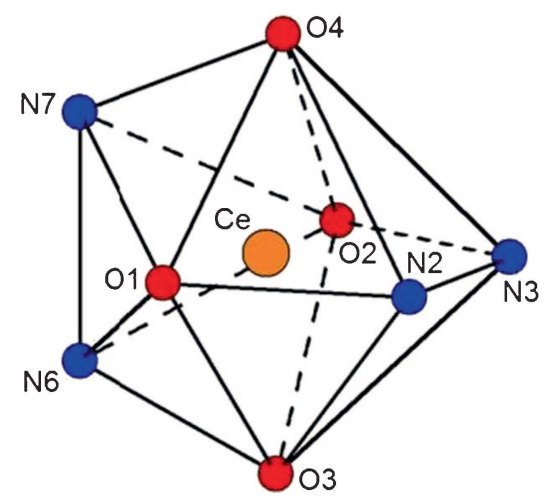

$\mathrm{C}-\mathrm{H} \cdots \mathrm{N}$ interaction involving the $\mathrm{babh}^{2-}$ amidate- $\mathrm{N}$ atom of one complex molecule and a $\mathrm{C}-\mathrm{H} \cdots \mathrm{Cl}$ interaction involving the babh ${ }^{2-}$ phenyl ortho $\mathrm{C}-\mathrm{H}$ of a second complex molecule (table 3). Thus, two $\mathrm{CH}_{2} \mathrm{Cl}_{2}$ molecules bridge two $\left[\mathrm{Ce}(\mathrm{babh})_{2}\right]$ molecules via two $\mathrm{C}-\mathrm{H} \cdots \mathrm{N}$ and two $\mathrm{C}-\mathrm{H} \cdots \mathrm{Cl}$ hydrogen bonds and form the centrosymmetric $\left\{\mathbf{1} \cdot \mathrm{CH}_{2} \mathrm{Cl}_{2}\right\}_{2}$ unit (figure 3 ). The phenyl rings $(\mathrm{C}(6)-\mathrm{C}(11)$ and $\mathrm{C}(13)-\mathrm{C}(18))$ of one babh ${ }^{2-}$ ligand in the $\left[\mathrm{Ce}(\mathrm{babh})_{2}\right]$ molecules of each $\left\{\mathbf{1} \cdot \mathrm{CH}_{2} \mathrm{Cl}_{2}\right\}_{2}$ unit are involved in $\pi-\pi$ interactions ( $\sim 3.7 \AA$ centroid-to-centroid distance) with the two adjacent dimeric units. As a result, a one-dimensional $\pi$ stacked assembly of $\left\{\mathbf{1} \cdot \mathrm{CH}_{2} \mathrm{Cl}_{2}\right\}_{2}$ is formed (figure 3 ). These intermolecular $\mathrm{C}-\mathrm{H} \cdots \mathrm{N}, \mathrm{C}-\mathrm{H} \cdots \mathrm{Cl}$ and $\pi-\pi$ interactions assisted self-assembly pattern of $1 \cdot \mathrm{CH}_{2} \mathrm{Cl}_{2}$ can be best described as 'ladder' type where, the steps are formed by the hydrogen bonds and the two sides are made by the $\pi-\pi$ interactions (figure 3 ).

In $2 \cdot \mathrm{H}_{2} \mathrm{O}$, the water molecule is involved in three intermolecular hydrogen bonds (table 3 ). It acts as acceptor in a strong $\mathrm{N}-\mathrm{H} \cdots \mathrm{O}$ hydrogen bond involving the protonated amide functionality of $\mathrm{Hbabh}^{-}$and donor in two $\mathrm{O}-\mathrm{H} \cdots \mathrm{N}$ hydrogen bonds involving the amidate- $\mathrm{N}$ atoms of two babh ${ }^{2-}$ ligands of two adjacent complex molecules. Thus each water molecule is connected to three complex molecules. Self-assembly via these intermolecular $\mathrm{N}-\mathrm{H} \cdots \mathrm{O}$ and $\mathrm{O}-\mathrm{H} \cdots \mathrm{N}$ hydrogen bonds leads to a two-dimensional 'sheet' like network of $2 \cdot \mathrm{H}_{2} \mathrm{O}$ (figure 4 ).

\subsection{Spectroscopic characteristics}

The amide functionality $\mathrm{N}-\mathrm{H}$ and $\mathrm{C}=\mathrm{O}$ stretches are observed as a medium intensity band at $\sim 3200 \mathrm{~cm}^{-1}$ and a strong band at $\sim 1655 \mathrm{~cm}^{-1}$, respectively in the infrared spectrum of the free Schiff base $\mathrm{H}_{2}$ babh. ${ }^{23,35}$ In case of $\mathbf{1}$, absence of both these bands confirms the deprotonated state of the amide functionalities of both coordinated ligands. In contrast, $2 \cdot \mathrm{H}_{2} \mathrm{O}$ exhibits a

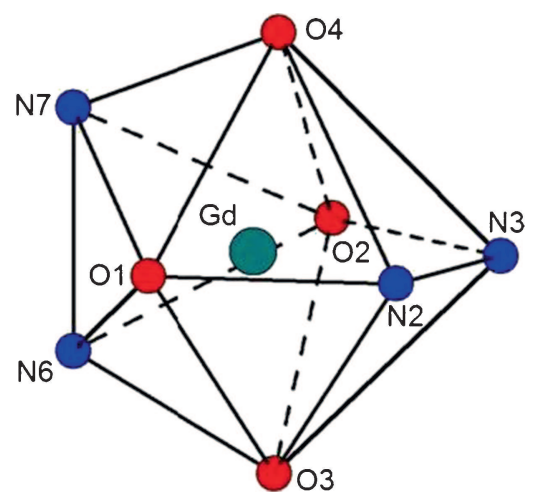

Figure 2. Dodecahedral coordination spheres around the metal centres in $\mathbf{1}$ and $\mathbf{2}$. 
Table 3. Hydrogen-bond parameters for $\mathbf{1} \cdot \mathrm{CH}_{2} \mathrm{Cl}_{2}$ and $\mathbf{2} \cdot \mathrm{H}_{2} \mathrm{O}$.

\begin{tabular}{lccc}
\hline Complex & $\mathrm{D}-\mathrm{H} \cdots \mathrm{A}$ & $\mathrm{d}(\mathrm{D} \cdots \mathrm{A})(\AA)$ & $<(\mathrm{DHA})\left(^{\circ}\right)$ \\
\hline $\mathbf{1} \cdot \mathrm{CH}_{2} \mathrm{Cl}_{2}$ & $\mathrm{C}(37)-\mathrm{H}(37 \mathrm{~B}) \cdots \mathrm{N}(4)$ & $3.348(3)$ & 143 \\
& $\mathrm{C}(29)-\mathrm{H}(29) \cdots \mathrm{Cl}(2)^{\mathrm{a}}$ & $3.566(2)$ & 138 \\
$\mathbf{2} \cdot \mathrm{H}_{2} \mathrm{O}$ & $\mathrm{N}(4)-\mathrm{H}(4) \cdots \mathrm{O}(5)$ & $2.821(12)$ & 168 \\
& $\mathrm{O}(5)-\mathrm{H}(5 \mathrm{~A}) \cdots \mathrm{N}(5)^{\mathrm{b}}$ & $2.924(12)$ & 173 \\
& $\mathrm{O}(5)-\mathrm{H}(5 \mathrm{~B}) \cdots \mathrm{N}(8)^{\mathrm{c}}$ & $2.889(13)$ & 160 \\
\hline
\end{tabular}

Symmetry transformations used to generate equivalent atoms:

${ }^{\mathrm{a}}-\mathrm{x},-\mathrm{y},-\mathrm{z}^{\mathrm{b}} \mathrm{x},-\mathrm{y}, \mathrm{z}+1 / 2^{\mathrm{c}}-\mathrm{x}+1 / 2, \mathrm{y}-1 / 2,-\mathrm{z}+1 / 2$.

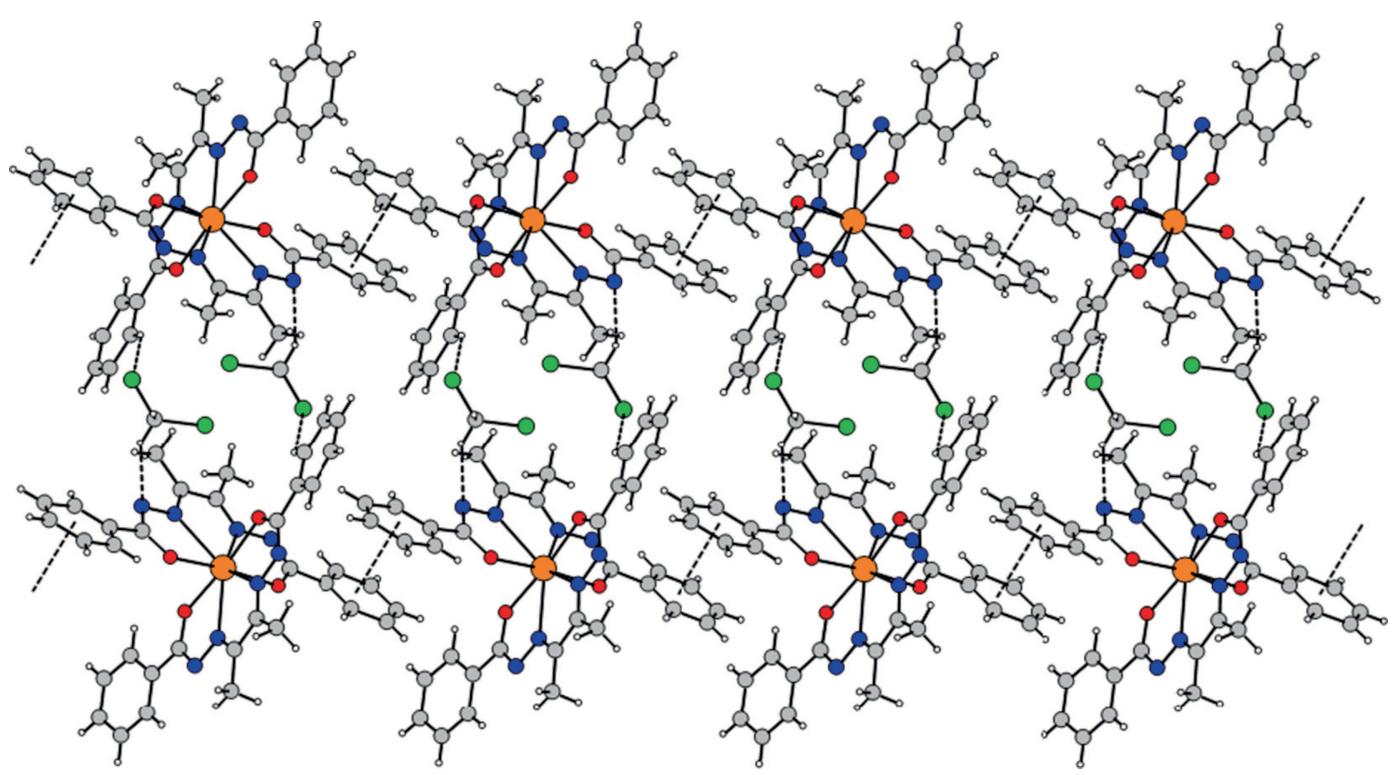

Figure 3. The ladder type structure formed by $\left[\mathrm{Ce}(\mathrm{babh})_{2}\right] \cdot \mathrm{CH}_{2} \mathrm{Cl}_{2}\left(\mathbf{1} \cdot \mathrm{CH}_{2} \mathrm{Cl}_{2}\right)$ via $\mathrm{C}-\mathrm{H} \cdots \mathrm{N}$, $\mathrm{C}-\mathrm{H} \cdots \mathrm{Cl}$ and $\pi-\pi$ interactions.

medium intensity band at $1624 \mathrm{~cm}^{-1}$. This band is most likely associated with the metal coordinated $\mathrm{C}=\mathrm{O}$ stretch of the protonated amide functionality in $\mathrm{Hbabh}^{-}$. However, no band assignable to the $\mathrm{N}-\mathrm{H}$ group of the protonated amide functionality could be detected presumably due to its participation in the $\mathrm{N}-\mathrm{H} \cdots$ O hydrogen bonding with the water molecule (vide supra). Instead, the broad relatively weak band observed at $\sim 3400 \mathrm{~cm}^{-1}$ is perhaps associated with the hydrogen bonded water molecule. Both complexes display the $\mathrm{C}=\mathrm{N}$ stretch as a medium intensity band at $\sim 1590 \mathrm{~cm}^{-1}$.

The electronic spectra of $\mathbf{1}$ and $\mathbf{2} \cdot \mathrm{H}_{2} \mathrm{O}$ have been collected using the corresponding dichloromethane solutions. The spectra are shown in figure 5. The cerium(IV) complex (1) displays a prominent shoulder at $\sim 510 \mathrm{~nm}$ and two strong and broad bands at $400 \mathrm{~nm}$ and 283 $\mathrm{nm}$ each followed by a shoulder. The gadolinium(III) complex $\left(\mathbf{2} \cdot \mathrm{H}_{2} \mathrm{O}\right)$ shows two similar strong and broad absorptions at $415 \mathrm{~nm}$ and $263 \mathrm{~nm}$ with several shoulders. Overall the spectral profiles of the two complexes are quite similar except for the $510 \mathrm{~nm}$ shoulder in the spectrum of $\mathbf{1}$. In general, $\mathrm{f}-\mathrm{f}$ transitions are sharp and unaffected by ligand field effect. ${ }^{36}$ In dichloromethane, $\mathrm{H}_{2}$ babh displays a single strong absorption at $305 \mathrm{~nm}$. Thus, for both complexes the absorption observed below $300 \mathrm{~nm}$ is attributed to intraligand transitions, while the absorption in the visible region is assigned to ligand-tometal charge transfer transitions. ${ }^{23,24,37,38}$

The ${ }^{1} \mathrm{H}$ NMR spectrum of the cerium(IV) complex (1) has been recorded using its $\mathrm{CDCl}_{3}$ solution. The protons of the four methyl groups of the two babh ${ }^{2-}$ ligands resonate as a singlet at $\delta 2.77 \mathrm{ppm}$. The ortho and the para protons of the four phenyl groups (two from each ligand) resonate as doublets at $\delta 7.95 \mathrm{ppm}(J=7.2 \mathrm{~Hz})$ and $\delta 7.35 \mathrm{ppm}(J=7.2 \mathrm{~Hz})$, respectively. The meta protons are observed as a triplet at $\delta 7.30 \mathrm{ppm}(J=7.2 \mathrm{~Hz})$.

The EPR spectra of the seven-electron paramagnetic gadolinium(III) complex $\left(\mathbf{2} \cdot \mathrm{H}_{2} \mathrm{O}\right)$ in powder phase at room temperature $(298 \mathrm{~K})$ and in frozen $(150 \mathrm{~K})$ dichloromethane are depicted in figure 6. Both spectra display several signals over the broad range of $0-750$ $\mathrm{mT}$. The profiles of the two spectra are quite similar except for the $0-300 \mathrm{mT}$ region. In this region, the powder spectrum shows two broad signals, while each 


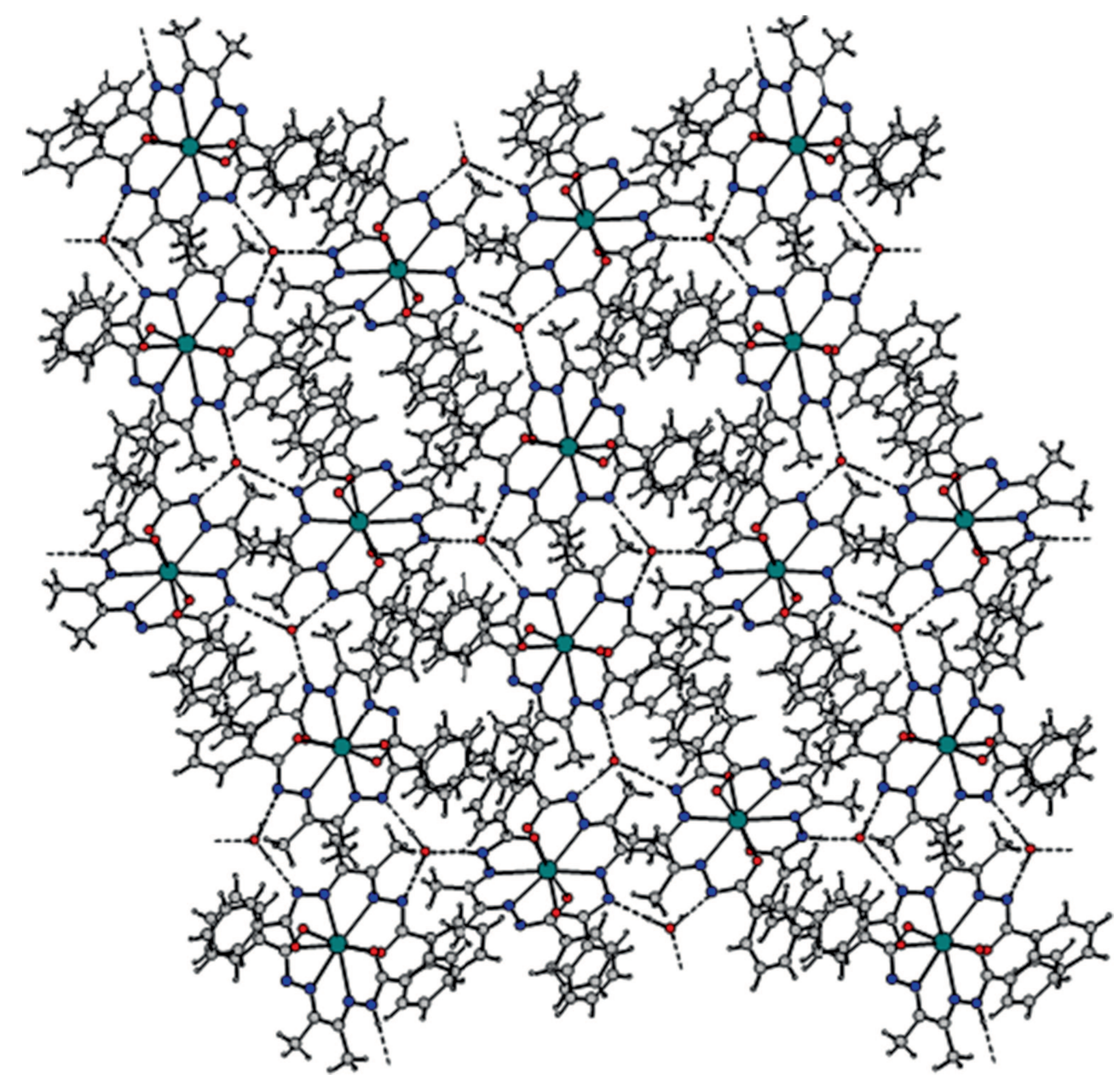

Figure 4. Two-dimensional network of $[\mathrm{Gd}(\mathrm{babh})(\mathrm{Hbabh})] \cdot \mathrm{H}_{2} \mathrm{O}\left(\mathbf{2} \cdot \mathrm{H}_{2} \mathrm{O}\right)$ through $\mathrm{N}-\mathrm{H} \cdots \mathrm{O}$ and $\mathrm{O}-\mathrm{H} \cdots \mathrm{N}$ hydrogen bonds.

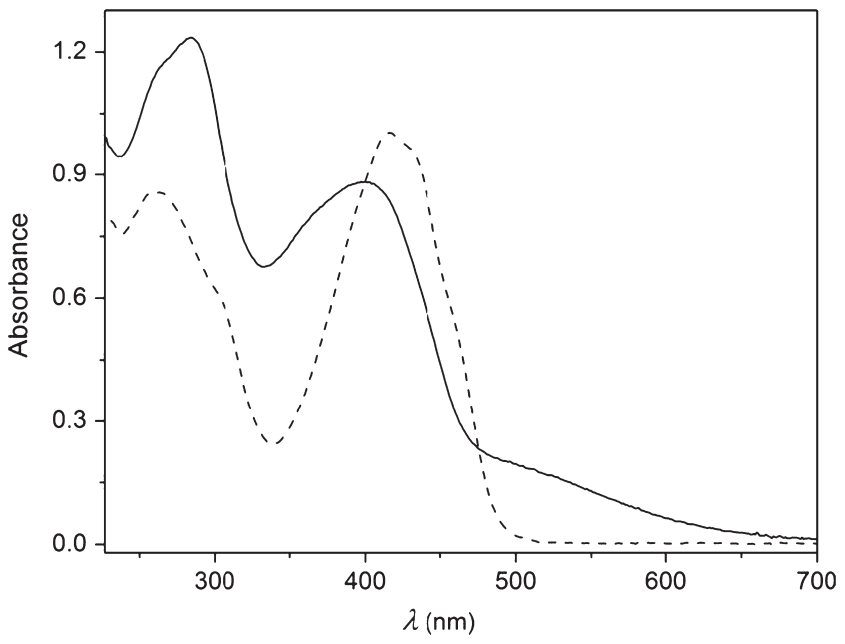

Figure 5. Electronic spectra of [Ce(babh) $\left.)_{2}\right](\mathbf{1})(--)$ and $\left.[\mathrm{Gd}(\mathrm{babh})(\mathrm{Hbabh})] \cdot \mathrm{H}_{2} \mathrm{O}\left(\mathbf{2} \cdot \mathrm{H}_{2} \mathrm{O}\right)(--)^{-}\right)$in dichloromethane.

of these two broad signals splits into three or more signals in the frozen solution spectrum. Above $300 \mathrm{mT}$ both spectra display several relatively weak signals. Such EPR spectral profiles with multiple signals over a

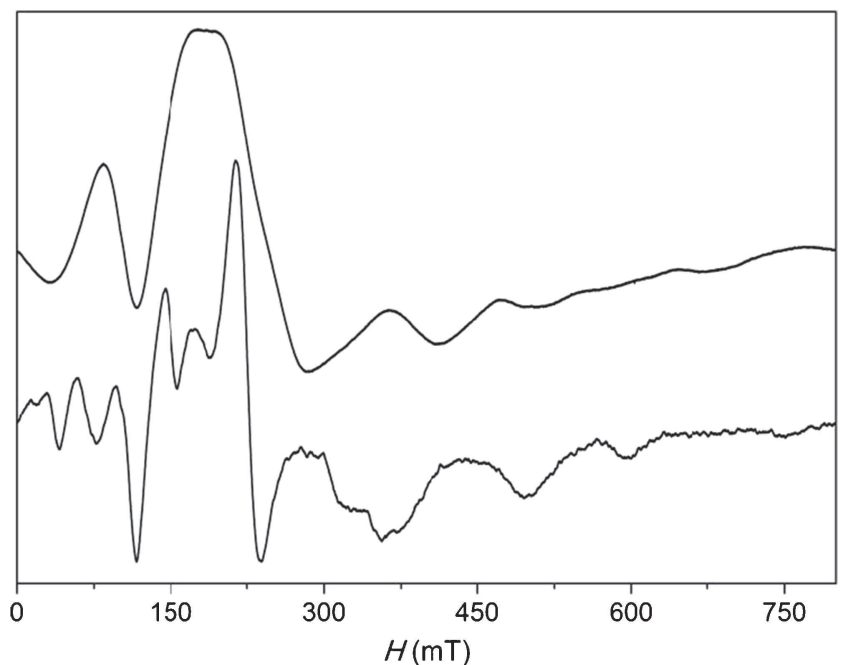

Figure 6. EPR spectra of $[\mathrm{Gd}(\mathrm{babh})(\mathrm{Hbabh})] \cdot \mathrm{H}_{2} \mathrm{O}\left(\mathbf{2} \cdot \mathrm{H}_{2} \mathrm{O}\right)$ in powder phase at $300 \mathrm{~K}$ (top) and in frozen $(150 \mathrm{~K})$ dichloromethane (bottom).

broad field range are quite common for gadolinium(III) complexes with $S=7 / 2$ spin state due to the zero-field and Zeeman effects. ${ }^{37,39,40}$ 


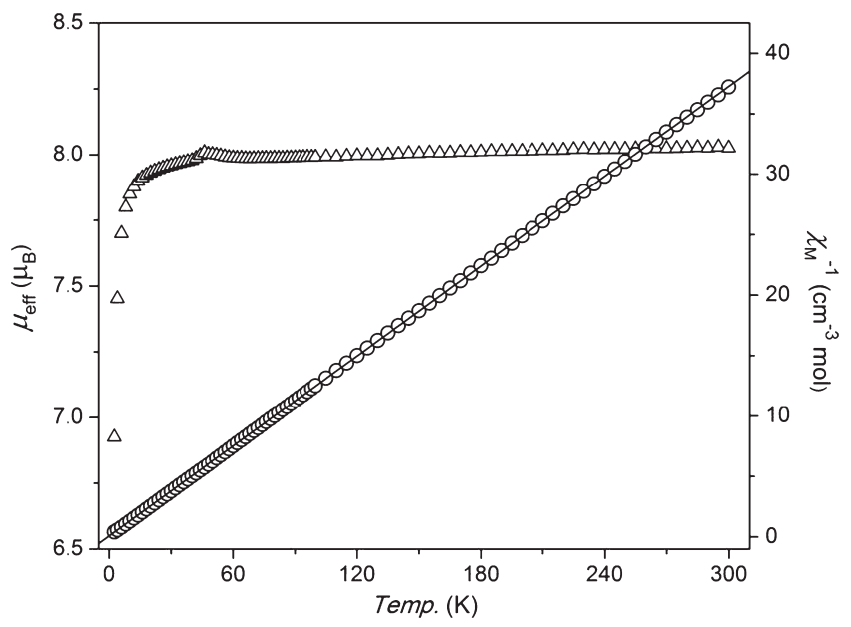

Figure 7. Temperature dependent effective magnetic moment $\left(\mu_{\text {eff }}\right)(\Delta)$ and inverse molar magnetic susceptibility $\left(\chi_{\mathrm{M}}^{-1}\right)(\mathrm{O})$ of $[\mathrm{Gd}(\mathrm{babh})(\mathrm{Hbabh})] \cdot \mathrm{H}_{2} \mathrm{O}\left(2 \cdot \mathrm{H}_{2} \mathrm{O}\right)$. The solid line represents the best least-squares fit using the parameters given in the text.

\subsection{Cryomagnetic properties of $2 \cdot \mathrm{H}_{2} \mathrm{O}$}

Variable temperature magnetic susceptibility measurements with a powdered sample of the gadolinium(III) complex $\left(\mathbf{2} \cdot \mathrm{H}_{2} \mathrm{O}\right)$ have been performed in the temperature range $300-3 \mathrm{~K}$. The $\mu_{\mathrm{eff}}$ values at 300 and $40 \mathrm{~K}$ are 8.03 and $7.98 \mu_{\mathrm{B}}$, respectively. Thus there is essentially no change of the $\mu_{\mathrm{eff}}$ in the temperature range $300-$ $40 \mathrm{~K}$ (figure 7). Between $40-10 \mathrm{~K}$ there is a gradual small decrease of the $\mu_{\text {eff }}$ and it reaches the value of $7.85 \mu_{\mathrm{B}}$ at $10 \mathrm{~K}$. Below $10 \mathrm{~K}$ it decreases rather sharply by a relatively larger amount and reaches the value of $6.93 \mu_{\mathrm{B}}$ at $3 \mathrm{~K}$. Crystal structure shows a hydrogen bond assisted two-dimensional 'sheet' like network of $\mathbf{2} \cdot \mathrm{H}_{2} \mathrm{O}$ (vide supra). Thus, the decrease of the $\mu_{\text {eff }}$ by about $1.1 \mu_{\mathrm{B}}$ in the temperature range $40-3 \mathrm{~K}$ is perhaps due to weak intermolecular antiferromagnetic interactions between the metal centres. Nonetheless, leastsquares fit of the data over the entire temperature range $(300-3 \mathrm{~K})$ to the Curie-Weiss law, $\chi_{\mathrm{M}}=\mathrm{C} /(T-\theta)$ indicates essentially Curie paramagnetic behaviour of $2 \cdot \mathrm{H}_{2} \mathrm{O}$ (figure 7 ). The best fit provided the Weiss constant $\theta$ as $-0.7 \mathrm{~K}$ and Curie constant $C$ as $8.1 \mathrm{emu} \mathrm{K}$ $\mathrm{mol}^{-1}$.

\section{Conclusions}

Complexes of cerium(IV) and gadolinium(III) with biacetyl bis(benzoylhydrazone) $\left(\mathrm{H}_{2}\right.$ babh) have been synthesized. They are characterized as $\left[\mathrm{Ce}(\text { babh })_{2}\right](\mathbf{1})$ and $[\mathrm{Gd}(\mathrm{babh})(\mathrm{Hbabh})] \cdot \mathrm{H}_{2} \mathrm{O}\left(\mathbf{2} \cdot \mathrm{H}_{2} \mathrm{O}\right)$ with the help of elemental analysis, X-ray crystallographic, spectroscopic and magnetic susceptibility measurements.
The physical properties of both complexes are consistent with the corresponding metal ion oxidation states and molecular formulas. X-ray structures of the solvated complexes, $1 \cdot \mathrm{CH}_{2} \mathrm{Cl}_{2}$ and $\mathbf{2} \cdot \mathrm{H}_{2} \mathrm{O}$, reveal 5,5,5-membered fused chelate rings forming ONNOcoordinating mode of $\mathrm{babh}^{2-}$ and $\mathrm{Hbabh}^{-}$. Two such meridionally disposed ligands form a distorted dodecahedral $\mathrm{N}_{4} \mathrm{O}_{4}$ coordination sphere around the metal centre in each of $\mathbf{1}$ and 2. Both $\mathbf{1} \cdot \mathrm{CH}_{2} \mathrm{Cl}_{2}$ and $\mathbf{2} \cdot \mathrm{H}_{2} \mathrm{O}$ are involved in intermolecular non-covalent interactions in their corresponding crystal lattices. These are $\mathrm{C}-\mathrm{H} \cdots \mathrm{Cl}, \mathrm{C}-\mathrm{H} \cdots \mathrm{N}$ and $\pi-\pi$ interactions for 1. $\mathrm{CH}_{2} \mathrm{Cl}_{2}$, and $\mathrm{O}-\mathrm{H} \cdots \mathrm{N}$ and $\mathrm{N}-\mathrm{H} \cdots \mathrm{O}$ hydrogen bonds for $\mathbf{2} \cdot \mathrm{H}_{2} \mathrm{O}$. Supramolecular self-assembly via these interactions leads to a one-dimensional 'ladder' type structure and a two-dimensional 'sheet' like network for $\mathbf{1} \cdot \mathrm{CH}_{2} \mathrm{Cl}_{2}$ and $\mathbf{2} \cdot \mathrm{H}_{2} \mathrm{O}$, respectively.

\section{Supplementary Information}

CCDC-1012274 and CCDC-1012275 contain the supplementary crystallographic data for $\mathbf{1} \cdot \mathrm{CH}_{2} \mathrm{Cl}_{2}$ and $2 \cdot \mathrm{H}_{2} \mathrm{O}$, respectively. These data can be obtained free of charge from the Cambridge Crystallographic Data Centre via www.ccdc.cam.ac.uk/data_request/cif.

\section{Acknowledgements}

T. Ghosh thanks the University Grants Commission (UGC), New Delhi for a research fellowship. We thank the Department of Science and Technology (DST), New Delhi and the UGC, New Delhi for the facilities provided under the FIST and the CAS programmes, respectively.

\section{References}

1. Parker D, Dickins R S, Puschmann H, Crossland C and Howard J A K 2002 Chem. Rev. 1021977

2. Cotton S A 2005 C. R. Chimie 8129

3. Tsukube H, Shinoda S and Tamiaki H 2002 Coord. Chem. Rev. 226227

4. Carr R, Evans N H and Parker D 2012 Chem. Soc. Rev. 417673

5. Hussain A and Chakravarty A R 2012 J. Chem. Sci. 124 1327

6. dos Santos C M G, Harte A J, Quinn S J and Gunnlaugsson T 2008 Coord. Chem. Rev. 2522512

7. Brunet E, Juanes O and Rodriguez-Ubis J C 2007 Curr. Chem. Biol. 111

8. Faulkner S, Pope S J A and Burton-Pye B P 2005 Appl. Spectrosc. Rev. 401

9. Armelaoa L, Quici S, Barigelletti F, Accorsi G, Bottaro G, Cavazzini M and Tondello E 2010 Coord. Chem. Rev. 254487

10. Binnemans K 2009 Chem. Rev. 1094283

11. Feng J and Zhang H 2013 Chem. Soc. Rev. 42387 
12. Sessoli R and Powell A K 2009 Coord. Chem. Rev. 253 2328

13. Luzon J and Sessoli R 2012 Dalton Trans 4113556

14. Zhang P, Guo Y -N and Tang J 2013 Coord. Chem. Rev. 2571728

15. Habib F and Murugesu M 2013 Chem. Soc. Rev. 423278

16. Aime S, Botta M and Terreno E 2005 Adv. Inorg. Chem. 57173

17. Woods M, Woessner D E and Sherry A D 2006 Chem. Soc. Rev. 35500

18. Aime S, Crich S G, Gianolio E, Giovenzana G B, Tei L and Terreno E 2006 Coord. Chem. Rev. 2501562

19. Werner E J, Datta A, Jocher C J and Raymond K N 2008 Angew. Chem. Intl. Ed. 478568

20. Shibasaki M and Yoshikawa N 2002 Chem. Rev. 102 2187

21. Li H -X, Zhu Y -J, Cheng M -L, Ren Z -G, Lang J -P and Shen Q 2006 Coord. Chem. Rev. 2502059

22. Visseaux M and Bonnet F 2011 Coord. Chem. Rev. 255 374

23. Ghosh T, Mukhopadhyay A, Dargaiah K S C and Pal S 2010 Struct. Chem. 21147

24. Ghosh T and Pal S 2010 Inorg. Chim. Acta 3633632

25. Bain G A and Berry J F 2008 J. Chem. Educ. 85532

26. SMART Version 5.630 and SAINT-plus Version 6.45 2003 Bruker-Nonius Analytical X-ray Systems Inc., Madison, Wisconsin, USA

27. Sheldrick G M 1997 SADABS, Program for Area Detector Absorption Correction, University of Göttingen, Göttingen
28. Sheldrick G M 2008 Acta Crystallogr., Sect. A 64 112

29. Farrugia L J 1999 J. Appl. Crystallogr. 32837

30. Macrae C F, Bruno I J, Chisholm J A, Edgington P R, McCabe P, Pidcock E, Rodriguez-Monge L, Taylor R, van de Streek J and Wood P.A 2008 J. Appl. Crystallogr. 41466

31. Spek A L 2002 Platon, A Multipurpose Crystallographic Tool Utrecht University, Utrecht, The Netherlands

32. Chen C, Chen H, Yan P and Hou G 2013 Li G Inorg. Chim. Acta 405182

33. Sommerer S O, Westcott B L, Cundari T R and Krause J A 1993 Inorg. Chim. Acta 209101

34. Benson M T, Cundari T R, Saunders L C and Sommerer S O 1997 Inorg. Chim. Acta 258127

35. Kemp W 1987 In Organic Spectroscopy (Macmillan: Hampshire) pp. 62-66

36. Yatsimirskii K B and Davidenko N K 1979 Coord. Chem. Rev. 27223

37. Prasad T K and Rajasekharan M V 2009 Inorg. Chem. 4811543

38. Chakraborty J, Ray A, Pilet G, Chastanet G, Luneau D, Ziessel R F, Charbonnière L J, Carrella L, Rentschler E, El Fallahe M S and Mitra S 2009 Dalton Trans. 10263

39. Szyczewski A, Lis S, Kruczyński Z, Pietrzak J, But S and Elbanowski M 1996 Acta Phys. Pol. A 90 345

40. Akilan P, Thirumavalavan M and Kandaswamy M 2003 Indian J. Chem. Technol. 10363 